\title{
Evaluation of the drinking water consumption in Lima city using the grey clustering method
}

\author{
Alexi Delgado, $\mathrm{PhD}^{1}$, John Soto, $\mathrm{BSc}^{2}$, Frank Valverde, $\mathrm{BSc}^{2}$ \\ ${ }^{1}$ Pontificia Universidad Católica del Perú - PUCP, Peru, kdelgadov@pucp.edu.pe \\ ${ }^{2}$ Universidad de Ciencias y Humanidades, Peru, yohsotos@uch.pe, fravalverdev@uch.edu.pe
}

\begin{abstract}
OMS indicated that a person should consume 100 liters of water per day to satisfy their needs. In some districts of Lima, the consumption of this resource is much higher, while elsewhere the consumption is under of the recommended. In this study, we realized an evaluation of the consumption of drinking water using the grey clustering method, which is based on the grey systems theory. The case study was carried out in 32 districts of Lima, Peru. As a result, a map on the situation of drinking water consumption was obtained. The results revealed that the districts that consume more water are San Isidro, Miraflores, La Molina, San Borja, and Lince. In addition, the districts that consume less water were Ancon, Puente Piedra, Villa el Salvador, and Independencia. Moreover, the results of the study could help to the central government or the authorities of districts to make the best decision about the equitable distribution of water to all districts of Lima city. The Grey clustering method showed interesting results and could be applied to other problems of the country, since this method considers the uncertainty into its analysis.
\end{abstract}

Keywords-Drinking water consumption, The grey clustering method, Water computacional modeling.

\section{INTRODUCTION}

Water is essential for life and all people must have a satisfactory supply (sufficient, safe and accessible), as an important social aspect [1] [2]. Improving access to safe drinking water could provide tangible benefits for health [3]. In addition, For the ONU, drinking water and sanitation are essential to life and health, considered that the realization of the human right to water is essential to healthy living which respects human dignity [4].

In Peru, a constitutional reform law was enacted in 2017 , recognizing the right of every person to progressively and universally access drinking water, prioritizing human consumption over other uses and promoting sustainable water management [5].

The Peruvian state has a company to supply drinking wáter, which is called SEDAPAL, this company provides potable water and sewerage services to the urban sector of the city of Lima, reported that an average Peruvian consumes a maximum of 163 liters of water per day, although the OMS indicates that a person has to consume 100 liters per day, also announced that the water deficit in Lima is $5.3 \mathrm{~m}^{3}$ per second and that San Isidro consumes 447 liters of drinking water per day, a figure that exceeds by $400 \%$ the estimate recommended by OMS [6]-[9].

Digital Object Identifier (DOI):

http://dx.doi.org/10.18687/LACCEI2019.1.1.421

ISBN: 978-0-9993443-6-1 ISSN: 2414-6390
In this study, we analyzed drinking water consumption in 32 districts of the city of Metropolitan Lima, applying the grey clustering method.

The grey glustering method is based on the grey systems theory, initially developed by Deng in 1985. Grey systems focus on the study of problems involving small samples or limited information; this fact makes the grey systems theory have a wide range of applicability, such as the evaluation of websites [10], transport management [11] or safety management [12].

In addition, the grey grouping method that could be applied by means grey incidence matrices or whitening weight functions. In this paper, we use center-point triangular whitening weight functions (CTWF), since it is applied mainly to check if the objects of observation belong to predetermined classes, called grey classes [13], as shown by the studies on a management of the water [14], or in innovation strategies [15]. Therefore, the specific objective of this study is to classify the districts of the Lima city, according to the level of drinking water consumption in the districts of Lima applying the CTWF method.

In this paper, Section II provides details of the CTWF method. In Section III, the case study is described, followed by the results and the discussion in Section IV. The conclusions are provided in Section V.

\section{Methodology}

First, a set of m objects, a set of $\mathrm{n}$ criteria, a set of $\mathrm{s}$ grey class, and a set of sample values xij $(i=1,2, \ldots, m ; j=1,2, \ldots$, $\mathrm{n})$, are assumed. Next, the steps of the CTWF method are presented as follows [16]:

Step 1: The criteria are divided into $s$ grey classes, and then their central points are determined $\left(\lambda_{1}, \lambda_{2} \ldots\right.$ and $\left.\lambda_{s}\right)$.

Step 2: Grey classes 0 and $(s+1)$ are added, with their central-points $\lambda_{0}$ and $\lambda_{s+1}$, see Fig. 1 .

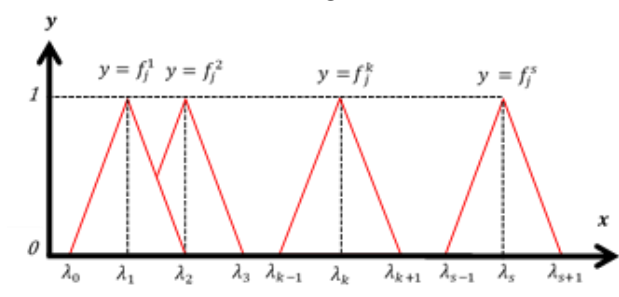

Fig. 1. CTWF [13]

For the $k^{\text {th }}$ grey class, $\mathrm{k}=1,2, \ldots, \mathrm{s}$, of the $j^{\text {th }}$ criterion, $\mathrm{j}=1,2, \ldots, \mathrm{n}$, for an observed value $x_{i j}$, the CTWF is calculated using Eq. 1 . 


$$
f_{j}^{k}\left(x_{i j}\right)= \begin{cases}0, & x \notin\left[\lambda_{k-1}, \lambda_{k+1}\right] \\ \frac{x-\lambda_{k-1}}{\lambda_{k}-\lambda_{k-1}}, & x \in\left[\lambda_{k-1}, \lambda_{k}\right] \\ \frac{\lambda_{k+1}-x}{\lambda_{k+1}-\lambda_{k}}, & x \in\left[\lambda_{k}, \lambda_{k+1}\right]\end{cases}
$$

Step 3: The global clustering coefficient $\sigma_{i}^{k}$ for the object $\mathrm{i}, \mathrm{i}=1,2, \ldots, \mathrm{m}$, with respect to the grey class $\mathrm{k}, \mathrm{k}=$ $1,2, \ldots, \mathrm{s}$, is calculated by the Eq. 2 .

$$
\sigma_{i}^{k}=\sum_{j=1}^{n} f_{j}^{k}\left(x_{i j}\right) \cdot \eta_{j}
$$

Where $f_{j}^{k}\left(x_{i j}\right)$ the CTWF and $\eta_{\mathrm{j}}$ is the weight of criterion $\mathrm{j}$.

Step 4: If $\max _{1 \leq k \leq s}\left\{\sigma_{i}^{k}\right\}=\sigma_{i}^{k^{*}}$, it is decided that object i belongs to the grey class $\mathrm{k}^{*}$.

\section{CASE STUdY}

The assessment of drinking water consumption was carried out in the Lima city, where we evaluated 32 districts, as shown in Fig. 2.

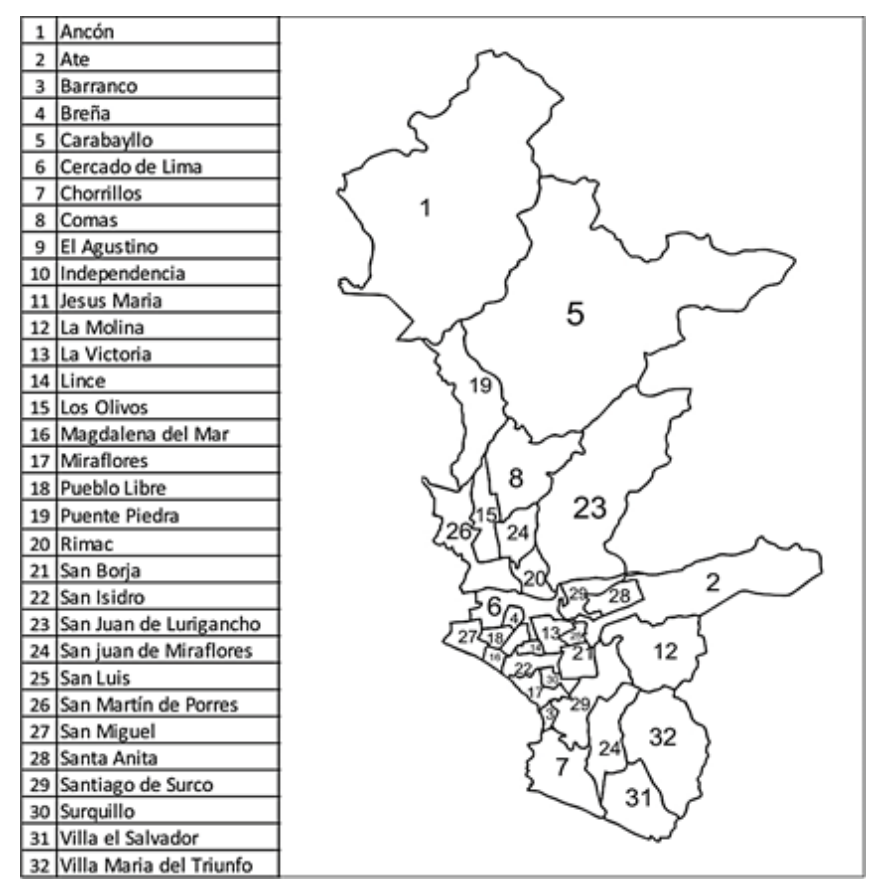

Fig. 2. Districts of the city of Lima.

\section{A. Description of the context}

In 2017, the distribution of drinking water in the city of Lima increased unlike in previous years, $85 \%$ already have water and only the upper areas of the city of Metropolitan Lima are missing. In this study, we evaluated the total drinking water consumption of the SEDAPAL report from
Peru, we obtained results of water consumption in each district of the city of Lima in the year 2017 [7]. The information is presented in Table I.

TABLE I. DRINKING WATER CONSUMPTION BY DISTRICT

\begin{tabular}{|c|c|c|c|}
\hline District & $\mathrm{L} / \mathrm{P} / \mathrm{D}$ & District & $\mathrm{L} / \mathrm{P} / \mathrm{D}$ \\
\hline $\mathbf{1}$ & 64.0 & $\mathbf{1 7}$ & 395.2 \\
\hline $\mathbf{2}$ & 90.1 & $\mathbf{1 8}$ & 202.8 \\
\hline $\mathbf{3}$ & 218.7 & $\mathbf{1 9}$ & 73.5 \\
\hline $\mathbf{4}$ & 176.1 & $\mathbf{2 0}$ & 111.7 \\
\hline $\mathbf{5}$ & 77.0 & $\mathbf{2 1}$ & 248.1 \\
\hline $\mathbf{6}$ & 182.5 & $\mathbf{2 2}$ & 447.5 \\
\hline $\mathbf{7}$ & 106.4 & $\mathbf{2 3}$ & 88.6 \\
\hline $\mathbf{8}$ & 89.9 & $\mathbf{2 4}$ & 98.4 \\
\hline $\mathbf{9}$ & 102.0 & $\mathbf{2 5}$ & 181.5 \\
\hline $\mathbf{1 0}$ & 76.7 & $\mathbf{2 6}$ & 110.3 \\
\hline $\mathbf{1 1}$ & 222.9 & $\mathbf{2 7}$ & 186.2 \\
\hline $\mathbf{1 2}$ & 258.6 & $\mathbf{2 8}$ & 99.2 \\
\hline $\mathbf{1 3}$ & 168.9 & $\mathbf{2 9}$ & 225.3 \\
\hline $\mathbf{1 4}$ & 240.1 & $\mathbf{3 0}$ & 182.2 \\
\hline $\mathbf{1 5}$ & 124.6 & $\mathbf{3 1}$ & 75.1 \\
\hline $\mathbf{1 6}$ & 216.7 & $\mathbf{3 2}$ & 78.7 \\
\hline
\end{tabular}

\section{B. Calculations using the CTWF method}

The calculations for the case study, based on the CTWF method, are preceded as follows.

Step 1: The scope of drinking water consumption figures [64; 447.5] was divided proportionally into five intervals or grey classes, in order to satisfy the need to reflect the characteristics of the specific problem under study [17]. The central points $\lambda_{1}, \lambda_{2}, \lambda_{3}, \lambda_{4}$, and $\lambda_{5}$, of the five grey classes are shown in Table II.

TABLE II. CENTRAL POINTS OF GREY CLASSES IN THE CASE STUDY

\begin{tabular}{|c|c|c|c|c|}
\hline $\begin{array}{c}\text { Very low } \\
\text { class }\left(\boldsymbol{\lambda}_{\mathbf{1}}\right)\end{array}$ & $\begin{array}{c}\text { low class } \\
\left(\boldsymbol{\lambda}_{\mathbf{2}}\right)\end{array}$ & $\begin{array}{c}\text { Medium class } \\
\left(\boldsymbol{\lambda}_{\mathbf{3}}\right)\end{array}$ & $\begin{array}{c}\text { High class } \\
\left(\boldsymbol{\lambda}_{\mathbf{4}}\right)\end{array}$ & $\begin{array}{c}\text { Very } \\
\text { class } \\
\left(\boldsymbol{\lambda}_{\mathbf{5}}\right)\end{array}$ \\
\hline $\mathrm{k}=1$ & $\mathrm{k}=2$ & $\mathrm{k}=3$ & $\mathrm{k}=4$ & $\mathrm{k}=5$ \\
\hline 103 & 180 & 257 & 334 & 411 \\
\hline
\end{tabular}

Step 2: The grey classes extended in two directions, adding the grey classes "extra low" and "extra high", respectively, with their central-points $\lambda 0$ and $\lambda 6$; as shown in Table III and Fig. 3.

TABLE III. CENTRAL POINTS OF EXTENDED GREY CLASSES

\begin{tabular}{|l|l|l|l|l|l|l|}
\hline \multicolumn{7}{|c|}{ Central points of extended grey classes } \\
\hline$\lambda_{0}$ & $\lambda_{1}$ & $\lambda_{2}$ & $\lambda_{3}$ & $\lambda_{4}$ & $\lambda_{5}$ & $\lambda_{6}$ \\
\hline
\end{tabular}

$17^{\text {th }}$ LACCEI International Multi-Conference for Engineering, Education, and Technology: "Industry, Innovation, And Infrastructure for Sustainable Cities and Communities", 24-26 July 2019, Jamaica. 


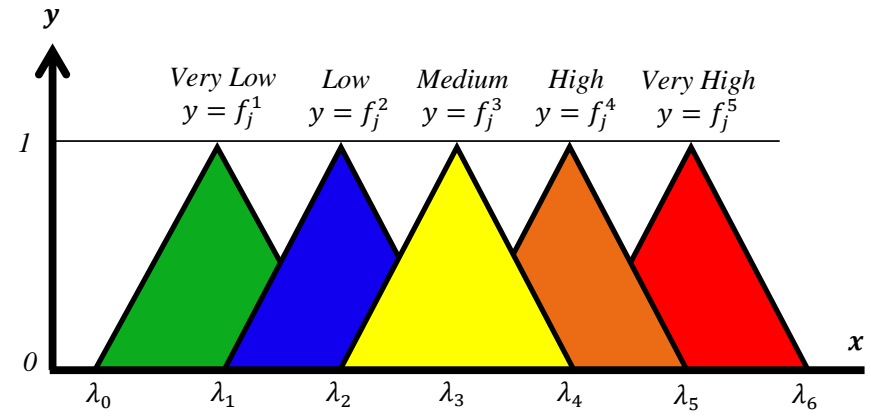

Fig. 3. CTWF for the case study.

Now, the values presented in Table III were substituted in Eq. 1, to obtain the CTWF of the five grey classes. The results are shown in Eq. 3-7:

$$
\begin{aligned}
& f_{1}^{1}(x)= \begin{cases}\frac{0,}{x-26} & x \notin[26,180] \\
\frac{180-x}{77}, & x \in[26,103]\end{cases} \\
& f_{1}^{2}(x)= \begin{cases}\frac{x-103}{77}, & x \in[103,180] \\
\frac{257-x}{77}, & x \in[180,257]\end{cases} \\
& f_{1}^{3}(x)= \begin{cases}\frac{0,180]}{77}, & x \in[180,257] \\
\frac{334-x}{77}, & x \in[180,334]\end{cases} \\
& f_{1}^{5}(x)= \begin{cases}\frac{0,180}{77}, & x \in[334,411] \\
\frac{x-334}{77}, & x \in[411,488]\end{cases} \\
& f_{1}^{4}(x)= \begin{cases}\frac{0,}{x-257} & x \notin[257,411] \\
\frac{411-x}{77}, & x \in[257,334]\end{cases}
\end{aligned}
$$

\begin{tabular}{|c|c|c|c|c|c|c|c|c|}
\hline District & 1 & 2 & 3 & 4 & 5 & 6 & 7 & 8 \\
\hline$f_{j}^{1}(x)$ & 0.49 & 0.83 & 0,00 & 0.05 & 0.66 & 0,00 & 0.96 & 0.82 \\
\hline$f_{j}^{2}(x)$ & 0,00 & 0,00 & 0.5 & 0.94 & 0,00 & 0.97 & 0.04 & 0,00 \\
\hline$f_{j}^{3}(x)$ & 0,00 & 0,00 & 0.5 & 0,00 & 0,00 & 0.03 & 0,00 & 0,00 \\
\hline$f_{j}^{4}(x)$ & 0,00 & 0,00 & 0,00 & 0,00 & 0,00 & 0,00 & 0,00 & 0,00 \\
\hline$f_{j}^{5}(x)$ & 0,00 & 0,00 & 0,00 & 0,00 & 0,00 & 0,00 & 0,00 & 0,00 \\
\hline District & 9 & 10 & 11 & 12 & 13 & 14 & 15 & 16 \\
\hline$f_{j}^{1}(x)$ & 0.99 & 0.66 & 0,00 & 0,00 & 0.14 & 0,00 & 0.72 & 0,00 \\
\hline$f_{j}^{2}(x)$ & 0,00 & 0,00 & 0.44 & 0,00 & 0.86 & 0.22 & 0.28 & 0.52 \\
\hline$f_{j}^{3}(x)$ & 0,00 & 0,00 & 0.56 & 0.98 & 0,00 & 0.78 & 0,00 & 0.48 \\
\hline$f_{j}^{4}(x)$ & 0,00 & 0,00 & 0,00 & 0.02 & 0,00 & 0,00 & 0,00 & 0,00 \\
\hline$f_{j}^{5}(x)$ & 0,00 & 0,00 & 0,00 & 0,00 & 0,00 & 0,00 & 0,00 & 0,00 \\
\hline District & 17 & 18 & 19 & 20 & 21 & 22 & 23 & 24 \\
\hline$f_{j}^{1}(x)$ & 0,00 & 0,00 & 0.62 & 0.89 & 0,00 & 0,00 & 0.81 & 0.94 \\
\hline$f_{j}^{2}(x)$ & 0,00 & 0.70 & 0,00 & 0.11 & 0,12 & 0,00 & 0,00 & 0,00 \\
\hline$f_{j}^{3}(x)$ & 0,00 & 0.29 & 0,00 & 0,00 & 0.88 & 0,00 & 0,00 & 0,00 \\
\hline$f_{j}^{4}(x)$ & 0.21 & 0,00 & 0,00 & 0,00 & 0,00 & 0,00 & 0,00 & 0,00 \\
\hline$f_{j}^{5}(x)$ & 0.79 & 0,00 & 0,00 & 0,00 & 0,00 & 0.53 & 0,00 & 0,00 \\
\hline District & 25 & 26 & 27 & 28 & 29 & 30 & 31 & 32 \\
\hline$f_{j}^{1}(x)$ & 0,00 & 0.91 & 0,00 & 0.95 & 0,00 & 0,00 & 0.64 & 0.68 \\
\hline$f_{j}^{2}(x)$ & 0.98 & 0.09 & 0.92 & 0,00 & 0.41 & 0.97 & 0,00 & 0,00 \\
\hline$f_{j}^{3}(x)$ & 0.02 & 0,00 & 0.08 & 0,00 & 0.59 & 0.03 & 0,00 & 0,00 \\
\hline$f_{j}^{4}(x)$ & 0,00 & 0,00 & 0,00 & 0,00 & 0,00 & 0,00 & 0,00 & 0,00 \\
\hline$f_{j}^{5}(x)$ & 0,00 & 0,00 & 0,00 & 0,00 & 0,00 & 0,00 & 0,00 & 0,00 \\
\hline
\end{tabular}

Step 3: Then, from Table I, the CTWF values for each district were calculated using equations $3-7$. The results are shown in Table IV.
TABLE IV. VALUES OF CTFW FOR EACH DISTRICT

Step 4: From the Table IV, $\max _{1 \leq k \leq s}\left\{\sigma_{i}^{k}\right\}$ was calculated for each district, the results are shown in Table V:

TABLE V. VALUES OF $\sigma_{i}^{k}$ FOR EACH DISTRICT

\begin{tabular}{|c|c|c|c|c|c|c|c|}
\hline $\mathbf{1}$ & $\mathbf{2}$ & $\mathbf{3}$ & $\mathbf{4}$ & $\mathbf{5}$ & $\mathbf{6}$ & $\mathbf{7}$ & $\mathbf{8}$ \\
\hline 0.49 & 0.83 & 0.50 & 0.94 & 0.66 & 0.97 & 0.96 & 0.82 \\
\hline $\begin{array}{c}\text { Very } \\
\text { Low }\end{array}$ & $\begin{array}{c}\text { Very } \\
\text { Low }\end{array}$ & $\begin{array}{c}\text { Medi } \\
\text { um }\end{array}$ & Low & $\begin{array}{c}\text { Very } \\
\text { low }\end{array}$ & Low & $\begin{array}{c}\text { Very } \\
\text { Low }\end{array}$ & $\begin{array}{c}\text { Very } \\
\text { Low }\end{array}$ \\
\hline $\mathbf{9}$ & $\mathbf{1 0}$ & $\mathbf{1 1}$ & $\mathbf{1 2}$ & $\mathbf{1 3}$ & $\mathbf{1 4}$ & $\mathbf{1 5}$ & $\mathbf{1 6}$ \\
\hline 0.99 & 0.66 & 0.56 & 0.98 & 0.86 & 0.78 & 0.72 & 0.52 \\
\hline $\begin{array}{c}\text { Very } \\
\text { Low }\end{array}$ & Very & Medi & Medi & Low & $\begin{array}{c}\text { Medi } \\
\text { um }\end{array}$ & $\begin{array}{c}\text { Very } \\
\text { Low }\end{array}$ & Low \\
\hline $\mathbf{1 7}$ & $\mathbf{1 8}$ & $\mathbf{1 9}$ & $\mathbf{2 0}$ & $\mathbf{2 1}$ & $\mathbf{2 2}$ & $\mathbf{2 3}$ & $\mathbf{2 4}$ \\
\hline 0.79 & 0.70 & 0.62 & 0.89 & 0.88 & 0.53 & 0.81 & 0.94 \\
\hline $\begin{array}{l}\text { Very } \\
\text { High }\end{array}$ & Low & $\begin{array}{c}\text { Very } \\
\text { Low }\end{array}$ & $\begin{array}{c}\text { Very } \\
\text { Low }\end{array}$ & $\begin{array}{c}\text { Medi } \\
\text { um }\end{array}$ & $\begin{array}{c}\text { Very } \\
\text { High }\end{array}$ & $\begin{array}{c}\text { Very } \\
\text { Low }\end{array}$ & $\begin{array}{c}\text { Very } \\
\text { Low }\end{array}$ \\
\hline $\mathbf{2 5}$ & $\mathbf{2 6}$ & $\mathbf{2 7}$ & $\mathbf{2 8}$ & $\mathbf{2 9}$ & $\mathbf{3 0}$ & $\mathbf{3 1}$ & $\mathbf{3 2}$ \\
\hline 0.98 & 0.91 & 0.92 & 0.95 & 0.59 & 0.97 & 0.64 & 0.68 \\
\hline Low & Very & Low & $\begin{array}{c}\text { Very } \\
\text { Ledi }\end{array}$ & $\begin{array}{c}\text { Low } \\
\text { um }\end{array}$ & $\begin{array}{c}\text { Very } \\
\text { Low }\end{array}$ & \begin{tabular}{c} 
Lery \\
\hline
\end{tabular} \\
\hline
\end{tabular}

\section{RESULTS AND DISCUSSION}

The results and the discussion, according to the specific objective in this study, are presented as follows:

\section{A. The Case Study}

Fig. 4, constructed from Table V, shows the following results:

First, in 2017, the districts that consume the most drinking water in Lima were San Isidro and Miraflores. 447.5 Lt. and 395.2 Lt. respectively.

Second, in 2017, the districts with the less water consumption in Lima were Ancon, Ate, Carabayllo, Chorrillos, Comas, Independencia, Los Olivos, Rimac, San Juan de Lurigancho, San Juan de Miraflores, San Martin de 
Porres, Santa Anita, Villa El Salvador, and Villa María del Triunfo.

Third, in 2017, the districts that were within the mean were Barranco, Jesus Maria, La Molina, Lince, San Borja, and Santiago de Surco. All results are presented in Fig. 4.

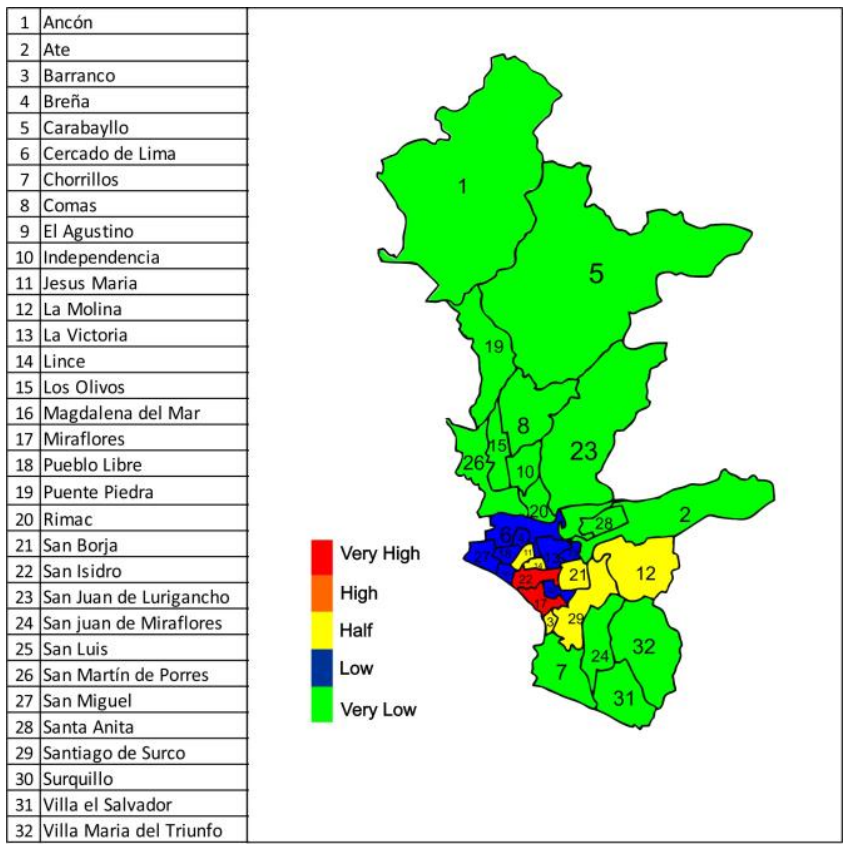

Fig. 4. Drinking water consumption level by districts.

\section{B. The grey clustering method}

An advantage of the grey clustering method is that it considers uncertainty within its analysis [13], as some classical approaches to multi-criteria analysis, such as Delphi[18] or the hierarchical analytic process (AHP) [19], do not consider the uncertainty within their analysis, due to the fact that the importance of the degrees of the criteria is precisely presupposed [20]. Therefore, it could be argued that the grey clustering method could be applied to different problems, which have a high level of uncertainty.

\section{CONCLUSIONS}

The grey clustering method determined and classified the districts with a high and lower drinking water consumption level in the Lima city. In addition, the results obtained in this work could help to the central government, the local authorities of the districts, or SEDAPAL to make the best decision about the level of drinking water consumption.

As a major advantage, the grey clustering method could be more effective than other classical multi-criteria methods, since it considers the uncertainty within its analysis. Moreover, as a major limitation, methods based on grey systems theory are not widely disseminated compared to others approaches based on multi-criteria analysis or statistical models. In addition, the grey clustering method could be improved and simplified by implementing a computer system.

In future studies, the grey clustering method could be applied to other types of social problems, in which the number of criteria or variables involved could be determined according to the particularities of each social type problem.

\section{REFERENCES}

[1] A. Delgado and I. Romero, "Social impact assessment on a hydrocarbon proyect using triangular whitenization weight functions," in CACIDI 2016 - Congreso Aergentino de Ciencias de la Informatica y Desarrollos de Investigacion, 2016.

[2] A. Delgado, "Social conflict analysis on a mining project using shannon entropy," in 2017 IEEE XXIV International Conference on Electronics, Electrical Engineering and Computing (INTERCON), 2017, pp. 1-4.

[3] OMS, "Guías para la calidad del agua potable," vol. Tercera Edición.

[4] ONU-Hábitat, "El derecho al agua."

[5] Congreso de la República de Perú, "Ley Nº 30588. Ley de Reforma constitucional que reconoce el derecho de acceso al agua como derecho constitucional," p. 2017, 2017.

[6] "SEDAPAL convoca a municipios para respaldar propuesta de cuidado del agua potable - Notas de Prensa - sedapal.com.pe."

[7] "San Isidro y Miraflores registran mayor consumo de agua potable por día - Notas de Prensa - sedapal.com.pe."

[8] "OMS | La cantidad de agua domiciliaria, el nivel del servicio y la salud," WHO, 2013.

[9] "OMS | Acerca de los sistemas de salud," WHO, 2015

[10] C. Bindu, M. Padmaja, and J. A. Chandulal, "Evaluating Web Sites Based on GHAP," Int. J. Comput. Sci. Eng., vol. 2, no. 3, pp. 674679, 2010.

[11] Y. Leng et al., "Evaluation on Transfer Efficiency at Integrated Transport Terminals through Multilevel Grey Evaluation," in 8th International Conference on Traffic and Transportation Studies, 2012, vol. 43, pp. 587-594.

[12] J. Wei, L. Zhou, F. Wang, and D. Wu, "Work safety evaluation in Mainland China using grey theory," Appl. Math. Model., vol. 39, no. 2, pp. 924-933, 2015.

[13] S. Liu and Y. Lin, Grey Systems: Theory and Applications. Berlin: Springer, 2010.

[14] M. Saqalli, S. Thiriot, and F. Amblard, "Investigating social conflicts linked to water resources trhough agent-based modelling," NATO Sci. Peace Secur. Ser., vol. 75, pp. 142-157, 2010.

[15] Y. Zhang, J. Ni, J. Liu, and L. Jian, "Grey evaluation empirical study based on center-point triangular whitenization weight function of Jiangsu Province industrial technology innovation strategy alliance," Grey Syst. Theory Appl., vol. 4, no. 1, pp. 124136, 2014.

[16] A. Delgado, "Citizen criminality assessment in lima city using the grey clustering method," in Proceedings of the 2017 IEEE 24th International Congress on Electronics, Electrical Engineering and Computing, INTERCON 2017, 2017.

[17] P. Corbetta, Metodología y técnicas de investigación social. Madrid: McGRAW-HILL, 2007.

[18] A. M. Mittnacht and C. M. Bulik, "Best nutrition counseling practices for the treatment of anorexia nervosa: A Delphi study," Int. J. Eat. Disord., pp. 111-122, 2014

[19] M. Kim, Y.-C. Jang, and S. Lee, "Application of Delphi-AHP methods to select the priorities of WEEE for recycling in a waste management decision-making tool," J. Environ. Manage., vol. 128, no. 0, pp. 941-948, 2013.

[20] A. Baykasoğlu and İ. Gölcük, "Development of a novel multipleattribute decision making model via fuzzy cognitive maps and hierarchical fuzzy TOPSIS," Inf. Sci. (Ny)., vol. 301, pp. 75-98, 2015 .

$17^{\text {th }}$ LACCEI International Multi-Conference for Engineering, Education, and Technology: "Industry, Innovation, And Infrastructure for Sustainable Cities and Communities”, 24-26 July 2019, Jamaica. 